\title{
Suplementasi multi mikronutrien dibandingkan Fe-asam folat terhadap kadar hemoglobin dan berat badan ibu hamil anemia
}

\author{
The effect of multi-micronutrient supplementation compared to Fe-folic acid on $\mathrm{Hb}$ level and weight of anemic \\ pregnant women
}

Herta Masthalina ${ }^{1}$, Mohammad Hakimi², Siti Helmyati ${ }^{3}$

\begin{abstract}
Background: As a part of global strategy to prevent micronutrient deficiency in pregnant mothers, UNICEF recommends the use of multi-micronutrients supplements as an initial program in developing countries. Therefore, it is necessary to investigate the effect of multi-micronutrient supplementation on $\mathrm{Hb}$ level and weight gain of anemic pregnant women in Lombok Tengah District.

Objective: To investigate the effect of multi-micronutrient compared to $\mathrm{Fe}$ - folic acid supplementation on $\mathrm{Hb}$ level and weight gain of anemic pregnant mothers.

Method: This was a quasi-experimental study with non equivalent control group design. Subjects in the intervention group were given multi-micronutrient supplements provided by UNICEF, whereas subjects in the control group were given Fe-folic acid supplements. The supplements were given daily to the two groups for 91 days. Hb level and weight were measured before and after intervention.

Result: Statistical analysis showed no significant differences $(p=0.96)$ in $\mathrm{Hb}$ level and weight gain $(p=0.454)$ between the two groups. The increase of $\mathrm{Hb}$ level and weight in the intervention group vs control group were $0,53 \pm 0,95 \mathrm{~g} / \mathrm{dL} v \mathrm{~s}$ $0,89 \pm 1,15 \mathrm{~g} / \mathrm{dL}$ and $4,89 \pm 2,71 \mathrm{~kg}$ vs 4,32 $\pm 1,75 \mathrm{~kg}$, respectively.

Conclusion: There were no significant differences in $\mathrm{Hb}$ level and weight gain between pregnant mothers consuming multi-micronutrient supplements compared to those consuming $\mathrm{Fe}-$ folic acid supplements.
\end{abstract}

KEY WORDS: multimicronutrients, Fe-Folic acid, Hb level, weight increase, anemic pregnant mothers

\begin{abstract}
ABSTRAK
Latar belakang: UNICEF merekomendasikan strategi global untuk mencegah kekurangan mikronutrien pada ibu hamil yaitu menggunakan multi mikronutrien untuk suplemen prenatal sebagai program pendahuluan di negara berkembang. Perlu dilakukan penelitian bagaimana pengaruh pemberian multi mikronutrien pada ibu hamil yang anemia terhadap kenaikan kadar hemoglobin (Hb) dan penambahan berat badan di Kabupaten Lombok Tengah.

Tujuan: Mengetahui pengaruh pemberian multi mikronutrien dibandingkan dengan pemberian Fe-asam folat pada ibu hamil yang anemia terhadap peningkatan kadar $\mathrm{Hb}$ dan penambahan berat badan.

Metode: Rancangan penelitian adalah penelitian quasi eksperimen dengan non equivalent control group design. Kelompok perlakuan diberi multi mikronutrien yaitu tablet multi mikronutrien untuk ibu hamil yang dibuat UNICEF sedangkan kelompok pembanding diberi Fe-asam folat. Eksperimen pada kedua kelompok dilakukan setiap hari selama 91 hari. Pengukuran kadar Hb dan berat badan dilakukan sebelum dan sesudah intervensi.

Hasil: Setelah diberikan intervensi selama 91 hari, rerata peningkatan kadar Hb pada kedua kelompok berbeda namun tidak bermakna ( $p>0,05)$. Kelompok perlakuan meningkat sebesar 0,53 $\pm 0,95 \mathrm{~g} / \mathrm{dL}$ sedangkan pada kelompok pembanding $0,89 \pm 1,15 \mathrm{~g} / \mathrm{dL}$. Demikian pula dengan rerata penambahan berat badan pada kedua kelompok berbeda

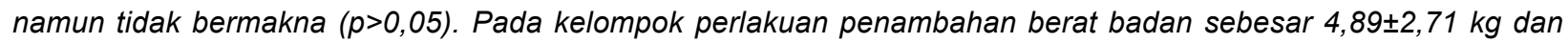
kelompok pembanding 4,32 $\pm 1,75 \mathrm{~kg}$.

Kesimpulan: Tidak ada perbedaan yang bermakna peningkatan kadar $\mathrm{Hb}$ dan penambahan berat badan antara ibu hamil yang mengonsumsi multi mikronutrien dan Fe-asam folat.
\end{abstract}

KATA KUNCI: multi mikronutrien, Fe-asam folat, kadar hemoglobin, penambahan berat badan, ibu hamil anemia

\footnotetext{
${ }^{1}$ Korepondensi: Jurusan Gizi Poltekkes Kemenkes Mataram, Jl. Praburangkasari Dasan Cermen, Mataram, Nusa Tenggara Barat, Telp (0370) 633837, e-mail: herta_tobing@yahoo.co.id

2 Bagian Obstetri dan Ginekologi, Fakultas Kedokteran Universtas Gadjah Mada, Jl. Farmako Sekip Utara Yogyakarta 55821

${ }^{3}$ Program Studi Gizi Kesehatan, Fakultas Kedokteran Universitas Gadjah Mada, Jl. Farmako, Sekip Utara Yogyakarta 55821, e-mail: siti_helmyati@ yahoo.com
} 


\section{PENDAHULUAN}

Masa kehamilan merupakan masa yang sangat penting karena pada masa ini kualitas seorang anak ditentukan. Pemenuhan gizi yang optimal pada masa ini akan berpengaruh terhadap pertumbuhan dan perkembangan janin serta kesehatan ibu, apabila asupan gizi pada ibu hamil tidak mencukupi kebutuhan maka kemungkinan akan terjadi gangguan pertumbuhan terhadap ibu maupun janin yang dikandungnya (1).

Asupan zat gizi yang kurang akan berpengaruh terhadap pertumbuhan dan status gizi, hal ini tercermin dari perubahan berat badan (BB) selama hamil dan status anemia ibu hamil (2). Anemia pada ibu hamil dapat mengakibatkan kurangnya oksigen yang ditranspor ke sel tubuh sehingga menimbulkan gejala letih, lesu, dan cepat lelah yang akhirnya akan mempengaruhi nafsu makan dan dapat berdampak pada BB ibu hamil secara tidak langsung (3). Penurunan kadar hemoglobin $(\mathrm{Hb})$ akan mempengaruhi kapasitas darah membawa oksigen sehingga setiap aktivitas fisik pada anemia akan menimbulkan sesak napas dan mengakibatkan kematian (4).

Sebagai bagian dari strategi global untuk mencegah kekurangan mikronutrien pada ibu hamil, United Nations Children's Fund(UNICEF) merekomendasikan penggunaan multi mikronutrien (MMN) untuk suplemen prenatal sebagai program pendahuluan di negara berkembang. Sejak tahun 2007 diberikan MMN sebagai pengganti tablet besi (Fe) kepada ibu hamil di tujuh Puskesmas di Kabupaten Lombok Tengah. Multi mikronutrien mengandung 15 jenis vitamin dan mineral yang paling penting untuk ibu hamil diantaranya vitamin $A$, vitamin $E$, vitamin $D$, vitamin $B_{1}$, vitamin $B_{2}$, niacin, vitamin $B_{6}$, vitamin $B_{12}$, asam folat, vitamin $\mathrm{C}, \mathrm{Fe}$, zink, tembaga, selenium, dan iodium. Penelitian sebelumnya membuktikan adanya hubungan antara konsumsi tablet MNN terhadap kenaikan kadar $\mathrm{Hb}$ maupun terhadap BB lahir bayi (5-8).

Berdasarkan uraian di atas, maka peneliti tertarik untuk mengetahui pengaruh pemberian MNN dibandingkan dengan pemberian Fe-asam folat terhadap peningkatan kadar $\mathrm{Hb}$ dan penambahan $\mathrm{BB}$ pada ibu hamil yang mengalami anemia di Kabupaten Lombok Tengah.

\section{BAHAN DAN METODE}

Penelitian ini adalah penelitian quasi eksperimen dengan non equivalent control group design. Kelompok perlakuan diberi MNN yaitu mikronutrien untuk ibu hamil yang dibuat UNICEF dalam bentuk tablet sedangkan kelompok pembanding diberi Fe-asam folat. Penelitian dilakukan di Kabupaten Lombok Tengah, Provinsi Nusa Tenggara Barat pada bulan Oktober 2009 - Januari 2010. Penetapan daerah penelitian berdasarkan data Dinas Kesehatan Lombok Tengah yaitu wilayah kerja Puskesmas yang mempunyai prevalensi anemia tertinggi pada ibu hamil yaitu Puskesmas Batu Nyala $(19,18 \%)$ untuk mewakili wilayah yang mendapatkan program tablet MNN sedangkan Puskesmas Janapria (9,88\%) untuk mewakili wilayah yang mendapatkan program tablet Feasam folat.

Populasi penelitian adalah seluruh ibu hamil anemia yang terdata oleh Puskesmas Batunyala dan Puskesmas Janapria Kabupaten Lombok Tengah. Besar sampel penelitian diperoleh menggunakan perhitungan rumus beda rata-rata dua populasi (9) dengan power $(\beta)$ sebesar $90 \%$, standar deviasi $(\alpha)$ sebesar 1,41 (8), dan perbedaan ratarata kenaikan kadar $\mathrm{Hb}$ dan penambahan $\mathrm{BB}$ selama hamil antara kelompok perlakuan dan kelompok pembanding sebesar $1\left(\mu_{1}-\mu_{2}=1\right)(8)$, sehingga jumlah sampel minimal yang diperlukan adalah 42 subjek dan untuk mengantisipasi kemungkinan subjek yang terpilih drop out dan loss to follow up maka jumlah sampel minimal menjadi 47 subjek. Penelitian ini mengambil subjek secara simple random sampling (acak sederhana) sebanyak 50 orang ibu hamil anemia pada setiap kelompok. Namun, sampel yang terlibat sampai akhir penelitian ini sebanyak 95 orang ibu hamil anemia yang terdiri dari 48 subjek pada kelompok perlakuan dan 47 subjek pada kelompok pembanding.

Kriteria inklusi subjek penelitian yaitu ibu hamil anemia trimester I dan II pada kunjungan pertama ke Puskesmas atau bidan desa, terdaftar sebagai sasaran penerimaan tablet MNN atau Fe-asam folat, tidak memiliki tanda penyakit berbahaya dengan cara melihat catatan kesehatan dari buku Kesehatan Ibu dan Anak (KIA) atau buku kesehatan kunjungan tiap bulan, dan bersedia menjadi subjek penelitian (written informed consent). Kriteria eksklusinya adalah subjek pindah alamat sehingga sulit dilacak atau subjek jatuh sakit dan memerlukan perawatan.

Kadar $\mathrm{Hb}$ diukur menggunakan metode Hemocue yang dikategorikan menjadi ibu hamil anemia jika mempunyai kadar Hb kurang dari $11 \mathrm{~g} / \mathrm{dL}$ pada usia kehamilan 5 - 24 minggu. Tablet MNN dan tablet Fe-asam folat diberikan pada ibu hamil pada usia kehamilan 5 - 24 minggu selama 91 hari (91 tablet) yang komposisi gizinya dapat dilihat pada Tabel 1. Kepatuhan konsumsi tablet Fe-asam folat atau MNN dicatat dengan bantuan tenaga kader untuk memberikan tablet kepada responden secara mingguan dan dikatakan patuh jika $100 \%$ mengonsumsi tablet. Form kepatuhan minum tablet Fe-asam folat/MNN dikumpulkan oleh enumerator setiap seminggu sekali ketika melakukan pemantauan.

Kenaikan BB ibu hamil ( $\mathrm{g} / \mathrm{minggu}$ ) adalah hasil ratarata kenaikan $\mathrm{BB}$ ibu hamil yang diukur menggunakan timbangan berat badan digital Camry kemudian dihitung dengan rumus $B B$ akhir dikurangi $B B$ awal dibagi pengurangan umur kehamilan akhir dengan umur kehamilan awal. Kenaikan BB dikategorikan menjadi dua yaitu tidak naik $(\triangle \mathrm{BB}<300 \mathrm{~g} / \mathrm{ming} \mathrm{gu}$ atau $\Delta \mathrm{BB}<$ $0,3 \mathrm{~kg} / \mathrm{minggu})$ dan naik $(\Delta \mathrm{BB}>300 \mathrm{~g} / \mathrm{ming}$ gu atau $\Delta$ $\mathrm{BB}>0,3 \mathrm{~kg} / \mathrm{minggu})$. Asupan zat gizi adalah rata-rata 
Herta Masthalina, Mohammad Hakimi, Siti Helmyati

Tabel 1. Perbandingan komposisi tablet MMN dan tablet Fe-asam folat berdasarkan kebutuhan ibu hamil

\begin{tabular}{lccc}
\hline \multirow{2}{*}{$\begin{array}{c}\text { Zat gizi } \\
\text { mikronutrien }\end{array}$} & Kebutuhan & \multicolumn{2}{c}{ Kandungan mikronutrien } \\
\cline { 3 - 4 } & & $\begin{array}{c}\text { Tablet } \\
\text { MMN }\end{array}$ & $\begin{array}{c}\text { Tablet } \\
\text { Fe-asam folat }\end{array}$ \\
\hline Vitamin A $(\mathrm{RE})$ & 800 & 800 & - \\
Vitamin D $(\mu \mathrm{g})$ & 5 & 5 & - \\
Vitamin $\mathrm{E}(\mathrm{mg})$ & 15 & 10 & - \\
Vitamin K $(\mathrm{mg})$ & 15 & - & - \\
Tiamin $(\mathrm{mg})$ & 1,3 & 1,4 & - \\
Riboflavin $(\mathrm{mg})$ & 1,4 & 1,4 & - \\
Niacin $(\mathrm{mg})$ & 17 & 18 & - \\
Asam folat $(\mu \mathrm{g})$ & 600 & 400 & 400 \\
Vitamin $\mathrm{B}_{6}(\mathrm{mg})$ & 1,7 & 1,9 & - \\
Vitamin $\mathrm{B}_{12}(\mu \mathrm{g})$ & 2,6 & 2,6 & - \\
Vitamin $\mathrm{C}(\mathrm{mg})$ & 85 & 70 & - \\
Kalsium $(\mathrm{mg})$ & 950 & - & - \\
Fosfor $(\mathrm{mg})$ & 600 & - & - \\
Magnesium & 270 & - & - \\
Besi $(\mathrm{mg})$ & 35 & 30 & 60 \\
Yodium $(\mu \mathrm{g})$ & 200 & 150 & - \\
Seng $(\mathrm{mg})$ & 11,5 & 15 & - \\
Selenium $(\mu \mathrm{g})$ & 35 & 65 & - \\
Mangan $(\mathrm{mg})$ & 2 & - & - \\
Tembaga $(\mathrm{mg})$ & - & 2 & - \\
\end{tabular}

Keterangan: $\mathrm{MMN}=$ multi mikronutrien

konsumsi energi, protein, vitamin $\mathrm{A}$, vitamin $\mathrm{C}$, zink, Fe, niasin, dan tiamin per hari yang berasal dari makanan ibu hamil berdasarkan perhitungan asupan rata-rata sehari yang diperoleh dengan food recall. Pola makan ibu hamil, makanan yang biasa dikonsumsi termasuk makanan pantangan diperoleh dengan mutiple recall. Lamanya hari recall makanan dihitung berdasarkan usual intake yaitu 5 hari. Waktu recall didistribusikan 1 kali sebelum intervensi, 3 kali selama intervensi (masing-masing 1 kali/bulan), dan 1 kali setelah intervensi. Asupan zat gizi dihitung dalam persentase angka kecukupan gizi (AKG) dan dikategorikan menjadi cukup ( $\geq 80 \%$ ) dan kurang (< $80 \%$ ). Data dikumpulkan oleh enumerator lulusan Diploma Gizi yang telah dilatih sebelumnya.

Data dianalisis secara kuantitatif menggunakan uji Chi-Square, t-test, dan regresi linear berganda dengan interval kepercayaan (IK) 95\%. Penelitian ini telah memperoleh kelaikan etik (ethical clearance) dari Komisi Etik Penelitian Kedokteran dan Kesehatan Fakultas Kedokteran Universitas Gadjah Mada

\section{HASIL}

\section{Karakteristik subjek penelitian}

Subjek yang mengikuti sampai akhir penelitian masingmasing sebanyak 48 subjek pada kelompok perlakuan dan 47 subjek pada kelompok pembanding. Alasan keluar dari penelitian pada kelompok perlakuan yaitu 1 orang mengalami abortus dan 1 orang melahirkan sebelum 38 minggu sedangkan pada kelompok pembanding 3 orang melahirkan sebelum 38 minggu. Sebelum intervensi, terlebih dahulu
Tabel 2. Karakteristik subjek penelitian

\begin{tabular}{|c|c|c|c|}
\hline \multirow{2}{*}{ Variabel } & \multicolumn{2}{|c|}{ Kelompok } & \multirow{2}{*}{$\mathbf{p}$} \\
\hline & Perlakuan & Pembanding & \\
\hline Umur (tahun) & & & 0,820 \\
\hline$<20$ & $10(20,8 \%)$ & $12(25,5 \%)$ & \\
\hline $20-35$ & $35(72,9 \%)$ & $33(70,2 \%)$ & \\
\hline$>35$ & $3(6,3 \%)$ & $2(4,3 \%)$ & \\
\hline Umur kehamilan (minggu) & & & 0,622 \\
\hline $5-12$ & $9(18,8 \%)$ & $11(23,4 \%)$ & \\
\hline $13-24$ & $39(81,2 \%)$ & $36(76,6 \%)$ & \\
\hline Pekerjaan & & & 0,249 \\
\hline Tidak bekerja & $16(33,3 \%)$ & $18(38,3 \%)$ & \\
\hline Buruh & $8(16,7 \%)$ & $5(10,6 \%)$ & \\
\hline Wiraswasta/dagang/jasa & $7(14,6)$ & $2(4,3 \%)$ & \\
\hline Petani & $16(33 \%)$ & $21(44,7 \%)$ & \\
\hline PNS/TNI/POLRI & 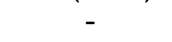 & $1(2,1 \%)$ & \\
\hline Lain-lain & $1(2,1 \%)$ & - & \\
\hline Pendidikan & & & 0,107 \\
\hline Tidak sekolah & $5(10,4 \%)$ & & \\
\hline SD & $17(35,4$ & 23( & \\
\hline SLTP & $16(33,3$ & $12(25$, & \\
\hline SLTA & $10(20,8 \%)$ & $3(6,4 \%)$ & \\
\hline $\mathrm{PT}$ & - & $2(4,3 \%)$ & \\
\hline Pekerjaan suami & & & 0,116 \\
\hline Tidak bekerja & - & - & \\
\hline Buruh & $15(31,3 \%)$ & $13(27,7 \%)$ & \\
\hline swasta/dagang/jasa & $8(16,7 \%)$ & $4(8,5 \%)$ & \\
\hline Peta & $16(33,3 \%)$ & $25(53,2 \%)$ & \\
\hline Pege & $4(10,4 \%)$ & - & \\
\hline PNS/TN & - & $1(2,1 \%)$ & \\
\hline Lain & $5(4,2 \%)$ & $4(8,9 \%)$ & \\
\hline Pendidika & & & $0,039^{*}$ \\
\hline Tidak sekolah & $2(4,2 \%)$ & $9(19,1 \%)$ & \\
\hline SD & $18(37,5 \%)$ & $17(36,8 \%)$ & \\
\hline & $17(35,4 \%)$ & $9(19,1 \%)$ & \\
\hline SLTA & $10(20,8 \%)$ & $7(14,9 \%)$ & \\
\hline PT & $1(2,1 \%)$ & $5(10,6 \%)$ & \\
\hline Pendapatan keluarga & & & 1,000 \\
\hline$<\operatorname{Rp} 555.000$ & $3(6,3 \%)$ & $3(6,4 \%)$ & \\
\hline Rp $555.000-1.000 .000$ & $28(58,3 \%)$ & $28(59,6 \%)$ & \\
\hline$>\operatorname{Rp} 1.000 .000$ & $17(35,4 \%)$ & $16(34,0 \%)$ & \\
\hline Paritas & & & 1,000 \\
\hline $1-4$ kali & $33(68,8 \%)$ & $32(68,1 \%)$ & \\
\hline & $15(31,3 \%)$ & $15(31,9 \%)$ & \\
\hline Jarak kehamilan (tahun) & & & 0,389 \\
\hline 0 & $26(54,2 \%)$ & $20(42,6 \%)$ & \\
\hline $1-<2$ & $3(6,3 \%)$ & $6(12,8 \%)$ & \\
\hline$>3$ & $19(39,6 \%)$ & $21(44,47 \%)$ & \\
\hline Kadar $\mathrm{Hb}$ awal $(\mathrm{g} / \mathrm{dL})^{\star *}$ & $10,06 \pm 0,70$ & $9,870 \pm 0,83$ & 0,236 \\
\hline BB awal $(\mathrm{kg})^{\star \star}$ & $50,74 \pm 4,06$ & $50,82 \pm 6,37$ & 0,947 \\
\hline
\end{tabular}

Keterangan :

*Bermakna $(\mathrm{p}<0,05)$; ${ }^{* *}$ Rerata $\pm \mathrm{SD} ; \mathrm{Hb}=$ hemoglobin; $\mathrm{BB}=$ berat badan

dilakukan pengukuran kadar $\mathrm{Hb}$ dan BB subjek penelitian. Rerata kadar $\mathrm{Hb}$ dan BB pada kedua kelompok sebelum intervensi tidak menunjukkan perbedaaan yang bermakna $(p>0,05)$. Berdasarkan hasil analisis, tidak ada perbedaan bermakna pada karakteristik ibu hamil antara kelompok perlakuan dan pembanding (Tabel 2).

\section{Asupan zat gizi}

Pada penelitian ini dilakukan multiple recall sebanyak lima kali kemudian hasil recall diterjemahkan ke dalam zat gizi. Penilaian asupan gizi meliputi asupan energi, 
Tabel 3. Rerata asupan zat gizi ibu hamil

\begin{tabular}{|c|c|c|c|c|c|}
\hline \multirow[b]{2}{*}{ Zat gizi } & \multicolumn{4}{|c|}{ Kelompok } & \multirow[b]{2}{*}{ p } \\
\hline & Perlakuan & $\begin{array}{c}\% \\
\text { AKG }\end{array}$ & Pembanding & $\begin{array}{c}\% \\
\text { AKG }\end{array}$ & \\
\hline $\begin{array}{l}\text { Energi } \\
\text { (kkal) }\end{array}$ & 1421,41 & 66,5 & 1462,09 & 69,8 & 0,343 \\
\hline Protein (g) & 44,35 & 66,2 & 45,19 & 67,2 & 0,476 \\
\hline Besi (mg) & 7,62 & 29,3 & 8,52 & 32,8 & 0,267 \\
\hline Seng (mg) & 5,44 & 47,3 & 6,06 & 52,7 & $0,006^{*}$ \\
\hline $\begin{array}{l}\text { Vitamin A } \\
\text { (RE) }\end{array}$ & 521,26 & 61,3 & 640,93 & 75,4 & 0,178 \\
\hline $\begin{array}{l}\text { Vitamin } B_{1} \\
(\mathrm{mg})\end{array}$ & 0,52 & 47,2 & 0,59 & 53,9 & 0,291 \\
\hline Niacin (mg) & 8,80 & 48,9 & 9,58 & 53,2 & 0,595 \\
\hline $\begin{array}{l}\text { Vitamin C } \\
\text { (mg) }\end{array}$ & 57,72 & 67,9 & 71,22 & 83,8 & 0,083 \\
\hline
\end{tabular}

Keterangan: $A K G$ = angka kecukupan gizi; ${ }^{*}$ Bermakna $(p<0,05)$

Tabel 4. Hasil penimbangan berat badan

\begin{tabular}{|c|c|c|c|c|}
\hline \multirow{2}{*}{ Kelompok } & \multicolumn{2}{|c|}{ Rerata \pm SD (kg) } & \multirow{2}{*}{$\begin{array}{c}\text { Delta } \\
\text { perubahan } \\
(\mathrm{kg})\end{array}$} & \\
\hline & BB awal & BB akhir & & \\
\hline & & & $4,89 \pm 2,71$ & 0,000 \\
\hline embanding & $50,82 \pm 6,37$ & $55,14 \pm 6,53$ & $4,32 \pm 1,75$ & 0,000 \\
\hline
\end{tabular}

Tabel 5. Analisis multivariat faktor yang mempengaruhi kadar hemoglobin

\begin{tabular}{lccc}
\hline \multicolumn{1}{c}{ Variabel } & Coefisien & B & $\begin{array}{c}\boldsymbol{p} \text {-value } \\
\text { (95\%Cl coefisien) }\end{array}$ \\
\hline Constant & $-5,44$ & & \\
Jumlah tablet & 0,07 & 0,290 & $0,04^{*}(0,02 ; 0,11)$ \\
Asupan vitamin C & 0,01 & 0,178 & $0,07(-0,001 ; 0,02)$ \\
Trimester & 0,305 & 0,117 & $0,257(0,226 ; 0,835)$ \\
Kepatuhan & 0,057 & 0,026 & $0,835(0,600 ; 0,486)$ \\
Asupan energi & 0,001 & 0,137 & $0,219(0,000 ; 0,002)$ \\
\hline
\end{tabular}

Keterangan: Bermakna* $p<0,05$

protein, zat besi, vitamin $C$, vitamin $A$, vitamin $B 1$, seng, dan niasin, serta persentase AKG untuk masing-masing zat gizi. Hasil uji t rerata asupan zat gizi ibu hamil menunjukkan perbedaan bermakna $(p<0,05)$ hanya pada asupan zat gizi seng (Tabel 3). Rerata asupan zat gizi pada kelompok perlakuan dan kelompok pembanding sebagian besar masih kurang dari AKG. Hasil analisis terhadap tingkat konsumsi zat gizi menunjukkan bahwa tidak ada perbedaan asupan antara kelompok perlakuan dan kelompok pembanding untuk masing-masing zat gizi $(p>0,05)$.

\section{Kenaikan kadar hemoglobin}

Hasil analisis menunjukkan peningkatan kadar $\mathrm{Hb}$ pada kelompok perlakuan sebesar $0,53 \pm 0,95 \mathrm{~g} / \mathrm{dL}$ setelah diberikan intervensi selama 91 hari dan terdapat perbedaan bermakna antara kadar $\mathrm{Hb}$ awal dan akhir $(p=0,000)$. Demikian pula kadar Hb kelompok pembanding yang mengalami peningkatan sebesar $0,89 \pm 1,15 \mathrm{~g} / \mathrm{dL}$ setelah diberikan intervensi selama 91 hari dan kadar $\mathrm{Hb}$ awal berbeda secara bermakna dengan kadar $\mathrm{Hb}$ akhir $(p=0,000)$. Namun, perbedaan kenaikan kadar $\mathrm{Hb}$ antara kedua kelompok tidak bermakna $(p>0,05)$.

\section{Kenaikan berat badan}

Tabel 4 menunjukkan adanya peningkatan bermakna pada rerata berat badan ibu hamil setelah intervensi pada kelompok perlakuan dan pembanding $(p=0,000)$. Hasil analisis statistik menunjukkan adanya relative risk sebesar 0,612 artinya subjek yang mendapat MNN kemungkinan tidak naik berat badannya 0,612 kali lebih besar dibandingkan subjek yang mendapat $\mathrm{Fe}$-asam folat. Lebih jauh lagi, hasil uji Chi Square menunjukkan tidak ada perbedaan yang bermakna kenaikan BB antara kelompok perlakuan dan pembanding $(p=0,225)$.

\section{Kepatuhan mengonsumsi tablet}

Hasil uji Chi Square menunjukkan terdapat perbedaan yang bermakna pada tingkat kepatuhan ibu hamil dalam mengonsumsi tablet antara kelompok perlakuan dan pembanding $(p=0,023)$. Hasil analisis relative risk sebesar 0,680 artinya subjek yang mendapat MNN kemungkinan menjadi tidak patuh 0,680 kali lebih besar dibandingkan subjek yang mendapat $\mathrm{Fe}$-asam folat. Pada kelompok perlakuan, rerata peningkatan kadar $\mathrm{Hb}$ setelah intervensi lebih tinggi pada subjek yang patuh yaitu sebsar $0,68 \mathrm{~g} / \mathrm{dL}$ sedangkan pada subjek yang tidak patuh rerata peningkatannya 0,38 $\mathrm{g} / \mathrm{dL}$. Demikian pula pada kelompok pembanding, rerata peningkatan kadar $\mathrm{Hb}$ setelah intervensi lebih tinggi pada subjek yang patuh $(1,52 \mathrm{~g} / \mathrm{dL})$ dibandingkan dengan subjek yang tidak patuh $(0,7 \mathrm{~g} / \mathrm{dL})$.

\section{Analisis faktor yang paling berpengaruh terhadap kadar hemoglobin dan kenaikan berat badan ibu hamil}

Besar pengaruh setiap variabel secara interaktif diketahui dengan melakukan analisis regresi linear berganda. Variabel yang diuji adalah variabel yang bermakna serta diduga memiliki kontribusi penting bagi kenaikan kadar $\mathrm{Hb}$. Adapun variabel yang masuk dalam analisis regesi linier berganda adalah trimester, jumlah tablet yang dikonsumsi, kepatuhan, asupan energi, dan asupan vitamin C. Hasil analisis multivariat menunjukkan bahwa variabel yang mempengaruhi kenaikan kadar $\mathrm{Hb}$ adalah jumlah tablet yang dikonsumsi sedangkan variabel asupan vitamin $\mathrm{C}$ merupakan variabel confounding (Tabel 5).

Berdasarkan Tabel 5 dapat disimpulkan bahwa dengan mengonsumsi tablet suplemen sebanyak 1 tablet maka akan menaikkan kadar $\mathrm{Hb}$ sebanyak 0,07 g/dL, sehingga diperoleh persamaan regresi kenaikan $\mathrm{Hb}=$ $-5,44+0,07$ jumlah tablet $+0,01$ vitamin $\mathrm{C}$. Beberapa 
variabel yang mempengaruhi BB ibu hamil yang masuk dalam analisis regesi linier berganda adalah jumlah dan kepatuhan konsumsi tablet suplemen. Hasil analisis multivariat dari kedua variabel tersebut menunjukkan bahwa variabel yang mempengaruhi kenaikan berat badan adalah jumlah tablet yang dikonsumsi. Berdasarkan hasil tersebut, maka dengan mengonsumsi tablet suplemen sebanyak 1 tablet akan menaikkan berat badan sebanyak $0,014 \mathrm{~kg}$, sehingga diperoleh persamaan regresi kenaikan berat badan $=-0,87+0,014$ jumlah tablet.

\section{BAHASAN}

\section{Tingkat asupan zat gizi}

Hasil analisis asupan makan menunjukkan bahwa rerata asupan zat gizi pada kedua kelompok secara statistik tidak berbeda kecuali asupan zink $(p<0,05)$. Sebagian besar asupan ibu hamil termasuk dalam kategori kurang $(<80 \%)$. Energi, protein, vitamin $\mathrm{C}$, vitamin $\mathrm{A}$, vitamin $\mathrm{B} 6, \mathrm{Fe}$, dan seng memiliki peran sangat penting dalam pembentukan $\mathrm{Hb}$. Besi (Fe) dan protein merupakan unsur utama dalam pembentukan $\mathrm{Hb}$ sedangkan sejumlah zat gizi lain seperti vitamin A, vitamin C, vitamin B6, dan zink berperan sebagai katalisator atau enzim pada berbagai tingkat pembentukan $\mathrm{Hb}$ dan metabolismenya (10). Pertumbuhan janin dan plasenta sangat bergantung pada asupan protein yang berasal dari ibu sehingga penambahan asupan protein sangat penting. Asupan energi dan protein yang kurang akan menghambat pertumbuhan janin. Hal ini berdampak tidak hanya pada berkurangnya berat badan dan pertumbuhan bayi tetapi juga pada penurunan jumlah sel dan perubahan beberapa parameter biokimia (11).

Sebagian besar protein yang dikonsumsi ibu hamil berasal dari nabati yang mengandung Fe non heme. Asupan vitamin C merupakan faktor yang sangat membantu penyerapan besi non heme dengan mengubah bentuk feri menjadi fero (10). Tingkat asupan vitamin $C$ pada kedua kelompok sebagian besar berada di bawah AKG, demikian pula dengan tingkat asupan zat besi. Absorbsi besi selain dipengaruhi oleh adanya faktor penunjang seperti vitamin $\mathrm{C}$, terdapat juga faktor penghambat seperti tanin pada teh, oksalat pada bayam, dan phosvitin dalam kuning telur (10). Absorpsi Fe juga dipengaruhi oleh status besi orang yang mengonsumsinya. Pada orang dengan defisiensi besi dapat mengabsorpsi zat besi heme dan non heme lebih banyak dibandingkan mereka yang status besinya normal (12).

Asupan energi subjek penelitian pada kedua kelompok berada di bawah AKG yaitu sebanyak 46 orang $(95,8 \%)$ pada kelompok perlakuan dan 40 orang $(85,1 \%)$ pada kelompok pembanding. Wanita hamil membutuhkan energi lebih banyak dibandingkan wanita tidak hamil, hal ini terutama diperlukan untuk pertumbuhan dan perkembangan janin, plasenta, dan jaringan reproduksi seperti uterus dan payudara. Di samping itu, penambahan energi diperlukan untuk meningkatkan cadangan lemak dan memenuhi kebutuhan yang meningkat akibat peningkatan metabolisme selama kehamilan. Kebutuhan energi meningkat pada umur kehamilan 10 - 30 minggu karena pada waktu tersebut terjadi peningkatan deposit lemak (11).

\section{Kenaikan kadar hemoglobin}

Rerata kadar $\mathrm{Hb}$ pada kedua kelompok mengalami peningkatan yang bermakna $(p=0,000)$. Penelitian ini sejalan dengan penelitian di Nigeria yang menyatakan pemberian tablet MNN atau Fe-asam folat dapat menaikkan kadar $\mathrm{Hb}$ pada ibu hamil (5). Rerata peningkatan kadar $\mathrm{Hb}$ pada kelompok pembanding $(0,89 \mathrm{~g} / \mathrm{dL})$ lebih tinggi daripada kelompok perlakuan $(0,53 \mathrm{~g} / \mathrm{dL})$. Hal tersebut dapat disebabkan oleh 3 hal, penyebab pertama yaitu kadar $\mathrm{Hb}$ awal yang tinggi berpengaruh terhadap penyerapan zat besi yang dikonsumsi dan terhadap peningkatan kadar $\mathrm{Hb}$ akhir. Pada subjek dengan kadar $\mathrm{Hb}$ yang rendah, akan lebih efisien dalam menyerap Fe sehingga peningkatan kadar $\mathrm{Hb}$ akhir menjadi lebih tinggi. Hasil penelitian menunjukkan pemeriksaan kadar $\mathrm{Hb}$ awal pada kelompok pembanding $(9,870 \pm 0,83 \mathrm{~g} / \mathrm{dL})$ lebih rendah dibandingkan rerata kadar $\mathrm{Hb}$ pada kelompok perlakuan $(10,06 \pm 0,70 \mathrm{~g} / \mathrm{dL})$.

Penyebab kedua, komposisi zat besi yang terkandung dalam tablet suplemen yang dikonsumsi pada kedua kelompok berbeda. Tablet MNN (kelompok perlakuan) mengandung $35 \mathrm{mg}$ zat besi sedangkan tablet Fe-Asam Folat (kelompok pembanding) mengandung $60 \mathrm{mg}$ zat besi. Didukung asupan zat besi dari makanan, maka diperoleh rerata asupan zat besi dari makanan lebih tinggi pada kelompok pembanding $(8,62 \mathrm{mg})$ dibandingkan kelompok perlakuan (7,52 mg). Kadar $\mathrm{Hb}$ akan meningkat jika ibu hamil mengonsumsi tablet dengan kandungan zat besi $60 \mathrm{mg}$ dan asam folat $400 \mu \mathrm{g}$ setiap hari selama 3 bulan (13).

Penyebab ketiga, rerata asupan zat gizi lebih tinggi pada kelompok pembanding daripada kelompok perlakuan. Kepatuhan ibu dalam mengonsumsi tablet yang diterima selama kehamilan merupakan faktor yang penting dalam meningkatkan kualitas kehamilannya. Kadar $\mathrm{Hb}$ akan meningkat $1 \mathrm{~g} / \mathrm{dL}$ dalam waktu 1-2 bulan jika ibu hamil mengonsumsi pil besi $60 \mathrm{mg}$, sehingga kepatuhan ibu hamil merupakan faktor penting dalam menjamin peningkatan kadar Hb ibu hamil (13). Penelitian ini menunjukkan bahwa ibu hamil yang mengonsumsi tablet suplemen dengan patuh pada kelompok perlakuan sebanyak 47,95\% dan kelompok pembanding 23,4\%. Hasil penelitian di Nigeria menunjukkan tingkat kepatuhan ibu hamil pada kelompok MNN sebanyak 44,4\% sedangkan kelompok Fe-asam 
folat $43,8 \%$ (5). Penyebab rendahnya kepatuhan ibu hamil mengonsumsi tablet suplemen adalah faktor kelupaan dan efek samping (mual, muntah, pusing), kurangnya kesadaran tentang pentingnya suplemen dan ancaman anemia bagi ibu hamil, takut bayi lahir besar, dan tidak adanya konseling yang khusus dari tenaga kesehatan (14).

Analisis multivariat terhadap beberapa variabel yang berhubungan dengan kadar $\mathrm{Hb}$ menunjukkan bahwa variabel jumlah tablet yang dikonsumsi berpengaruh terhadap kadar $\mathrm{Hb}$ dengan memperhatikan asupan zat gizi khususnya vitamin $\mathrm{C}$. Jumlah tablet minimal yang dikonsumsi ibu hamil pada kelompok perlakuan adalah 61 tablet dan maksimal 91 tablet, sedangkan untuk kelompok pembanding konsumsi terendah 75 tablet dan tertinggi 91 tablet. Penelitian menunjukkan bahwa pemberian $30 \mathrm{mg}$ zat besi per hari selama 4 minggu secara teratur dapat meningkatkan kadar Hb sekitar 2 g/dL (4). Namun, diperlukan penyuluhan untuk memotivasi subjek agar patuh dalam mengonsumsi tablet. Semakin pendek interval distribusi besi maka akan semakin baik karena semakin sering terjadi kontak antara petugas kesehatan dengan ibu hamil (12).

Selain jumlah tablet yang dikonsumsi, perlu juga memperhatikan asupan vitamin C. Hasil penelitian menunjukkan rerata asupan vitamin $\mathrm{C}$ pada kelompok perlakuan sebesar $67,90 \%$ AKG dan kelompok pembanding sebesar 83,78\% AKG. Vitamin C menghambat hemosiderin yang sukar dimobilisasi untuk membebaskan besi bila diperlukan. Absorbsi besi dalam bentuk non heme akan meningkat menjadi empat kali lipat bila tersedia vitamin C. Vitamin $\mathrm{C}$ berperan memindahkan besi dari transferin di dalam plasma ke feritin hati (10). Hal ini sesuai dengan penelitian yang menunjukkan bahwa pemberian $50 \mathrm{mg}$ vitamin $\mathrm{C}$ setiap hari selama 2 bulan mampu menaikkan kadar $\mathrm{Hb}$ (15). Penambahan sekurang-kurangnya $50 \mathrm{mg}$ vitamin $\mathrm{C}$ ke dalam makanan, baik dalam bentuk murni atau sayuran dan buah-buahan akan meningkatkan penyerapan zat besi (3).

\section{Penambahan berat badan}

Selain dari asupan energi dan protein, banyak faktor yang dapat mempengaruhi kenaikan BB ibu hamil antara lain keadaan ekonomi, paritas, umur ibu, pendidikan ibu, aktivitas, anemia, dan status gizi (11). Rerata kenaikan BB ibu hamil pada kelompok perlakuan lebih tinggi dibandingkan kelompok pembanding meskipun perbedaan kenaikan BB secara statistik tidak bermakna $(p=0,96)$. Hasil penelitian yang sama di Nusa Tenggara Barat menunjukkan bahwa tidak ada perbedaan bermakna penambahan BB ibu antara ibu hamil yang mengonsumsi multi gizi mikro dan Fe-asam folat (16).

Hasil penelitian ini menunjukkan bahwa ibu hamil anemia yang mengalami kenaikan BB sebanyak 39 orang $(69,6 \%)$ sedangkan jumlah ibu hamil tidak anemia yang naik berat badannya sebanyak 30 orang (76,9\%). Anemia yang berat dapat menimbulkan gejala pada saluran pencernaan yang umumnya berhubungan dengan defisiensi zat besi seperti anoreksia (tidak ada nafsu makan), nausea, konstipasi, diare, dan stomatis (sariawan lidah dan mulut) yang nantinya akan mempengaruhi asupan zat gizi. Sebaliknya, jika kelebihan zat besi menyebabkan kondisi melemah yang dapat menyebabkan kerusakan hati, jantung, pankreas, dan organ lainnya (17).

Analisis multivariat terhadap beberapa variabel yang berhubungan dengan kenaikan BB menunjukkan bahwa variabel yang berpengaruh terhadap kenaikan BB ibu hamil adalah jumlah tablet suplemen yang dikonsumsi. Komposisi pada tablet MNN lebih lengkap kandungan mikronutriennya dibandingkan tablet Fe-asam folat. Selain mengandung zat besi dan asam folat juga mengandung vitamin B yang dapat meningkatkan nafsu makan dan mencegah mual serta muntah pada masa kehamilan sehingga dengan memberikan multi mikronutrien status gizi ibu hamil dapat lebih optimal (18).

\section{SIMPULAN DAN SARAN}

Terdapat perbedaan peningkatan kadar $\mathrm{Hb}$ dan penambahan berat badan pada ibu hamil yang anemia antara yang diberi multi mikronutrien dibandingkan dengan Fe-asam folat. Namun, perbedaan tersebut tidak berbeda bermakna. Cara memaksimalkan efektivitas suplementasi untuk meningkatkan kadar $\mathrm{Hb}$ ibu hamil yaitu dengan mengonsumsi makanan sesuai dengan kecukupan yang dianjurkan menurut usia kehamilan. Selain itu, pemerintah perlu mempertimbangkan untuk pemberian makanan tambahan (PMT) bagi ibu hamil serta meningkatkan kandungan Fe pada suplemen MMN menjadi 60 mg.

\section{RUJUKAN}

1. Paath EF, Rumadasih $Y$, Heryati. Gizi dalam kesehatan reproduksi. Jakarta: Penerbit Buku Kedokteran EGC; 2005.

2. Lubis Z. Gizi ibu hamil, makalah pengantar falsafah sains program pascasarjana. Bogor: Institut Pertanian Bogor; 2003.

3. De Maeyer EM. Pencegahan dan pengawasan anemia defisiensi besi. Ronardy, editor. Jakarta: Widya Medika; 1995.

4. Vijayaraghavan K. Anemia karena defisiensi zat besi. Dalam: Gibney MJ, Margetts BM, Kearney JM, Arab L, editor. Gizi kesehatan masyarakat. Jakarta: EGC; 2009.

5. Zagre NM, Desplats G,Adou P, MamadoultaibouA,Aguayo VM. Prenatal multiple micronutrient supplementation has greater impact on birthweight than supplementation with 
iron and folic acid - a cluster randomized, double blind, controlled programmatic study in rural Niger. Food Nutr Bull 2007;28(3):317-27.

6. Gupta P, Ray M, Dua T, Radhakrisman G, Kumar $\mathrm{R}$, Sachdev. Multimicronutrient supplementation for undernourished pregnant women and birth size of their offspring - a double blid, randomized, placebo controlled trial. Arch Pediatr Adolesc Med [serial online] 2007 Jan [cited 2009 Jun 1];161(1):58-64. Available from: URL: http.//www.archpediatrics.com

7. Vaidya A, Savilla N, Shrestha BM, Costello AM, Manandhar D, Oarin D. Effect of antenatal multiple micronutrient supplementation on children's weight and size at 2 years of age in Nepal: follow-up of a double blind randomised controlled trial. Lancet 2008;371(9611):492-9.

8. Zeng L, Cheng Y, Dang S, Yan H, Dibley MJ, Chang $\mathrm{S}$, Kong L. Impact of micronutrient supplementation during pregnancy on birth weight, duration of gestation, and perinatal mortality in rural western China double blind cluster randomised controlled trial. BMJ 2008;337:1-11.

9. Lemeshow S, Hosmer Jr DW, Klar J, Lwanga SK. Besar sampel dalam penelitian kesehatan. Pramono D. 1997 (Alih bahasa). Yogyakarta: UGM Press; 1997.

10. Almatsier S. Prinsip dasar ilmu gizi. Jakarta: PT. Gramedia Pustaka Utama; 2001.
11. Institute of Medicine. Nutrition during pregnancy, weight gain and nutrient supplement. Washington: National Academi Press; 1990.

12. Husaini MA. Study nutritional anemia an assesment of information compilation for supporting and formulating national policy and program. Jakarta: Direktorat Bina Gizi Masyarakat Depkes dan Pusat Penelitian dan Pengembangan Gizi Depkes; 1989.

13. Gillespie S. Major Issues in the control of iron deficiency, the micronutrient initiative. Canada: UNICEF; 1998.

14. Winichagoon P. Prevention and control of anemia: Thailand experiences. J Nutr 2002;132(4):862S-6S.

15. Ulinuha. Pengaruh pemberian vitamin $C$ terhadap peningkatan kadar hemoglobin ibu hamil yang mendapat suplementasi kapsul besi. Yogyakarta: Fakultas Kedokteran Universitas Gadjah Mada; 2003.

16. Umniyati. Pengaruh suplemen multi gizi mikro terhadap penambahan berat badan hamil: sebuah studi prospektif di Lombok. [serial online] 2007 [cited 2009 March 20]. Available from: URL: http.//www.klikdokter.com

17. Price SA, Mc Carthy LW. Patofisiologi proses-proses penyakit. Jakarta: EGC; 1994.

18. Allen LH, Peerson JM. Maternal micronutrient suplementation study group (MMSG). Impact of multi micronutrient versus iron-folic acid supplements on maternal anemia and micronutrient status in pregnancy. Food Nutr Bull 2009;3(4):S527-32. 